\title{
Carne para alimento de rádios e discos o conceito de música popularesca na obra musicológica de Mário de Andrade
}

\author{
Juliana Pérez González ${ }^{1}$
}

Resumo

Este artigo revisa o uso da expressão música popularesca na obra musicológica de Mário de Andrade (1893-1945). Tudo parece indicar que o escritor modernista a utilizou, inicialmente, para descrever um tipo de repertório intermediário entre a música folclórica e a música erudita. Mais tarde, na medida em que a música popular urbana se consolidou, Mário de Andrade empregou "música popularesca" para denominar essa nova música, que era semelhante - mas não igual - à música folclórica. Esta expressão não possuía o caráter depreciativo do termo "submúsica", usado pelo escritor para qualificar obras "de aplauso fácil". A leitura apresentada difere da maneira como tradicionalmente a historiografia musical tem compreendido a expressão música popularesca e, por tanto, convida a se repensar parte da obra musicológica do escritor ${ }^{2}$.

\section{Palavras-chaves}

Música popularesca, conceito, Mário de Andrade.

Recebido em $1^{\circ}$ de novembro de 2012

Aprovado em 11 de março de 2013

GONZALÉZ, Juliana Pérez. Carne para alimento de rádios e discos: o conceito de música popularesca na obra musicológica de Mário de Andrade. Revista do Instituto de Estudos Brasileiros, Brasil, n.57, p. 139-160, 2013. D0I: http://dx.doi.org/10.11606/issn.2316-901X.v0i57p139-160

1 Universidade de São Paulo (USP, São Paulo, SP, Brasil).

2 Este artigo faz parte de minha dissertação de mestrado, intitulada Da música folclórica à música mecânica. Uma história do conceito de música popular por intermédio de Mário de Andrade (I893-1945), defendida no Departamento Programa de Pós-graduação em História Social, Departamento de História, FFLCH -USP, em março de 2012. 


\title{
Meat for the radios and records Música popularesca Concept in Musicological Work of Mário de Andrade
}

\author{
Juliana Pérez González
}

\begin{abstract}
In this paper I analyzed the use of the expression "música popularesca" over the musicological work of Mário de Andrade (1892 - 1945). Apparently, Mário de Andrade used it to describe a type of repertoire somewhere between folk music and classical music. After the consolidation of the urban popular music, Mário de Andrade used "música popularesca" to denominate this new kind of music, which was similar - but not identical - to folk music. This expression had no pejorative connotation, unlike the word "sub música" used by the same author to label works as "of easy applause". This approach is different from the traditional one that the musical historiography has over the expression "música popularesca" and, therefore, invites to debate some of the Mario de Andrade's musicological works.
\end{abstract}

Keywords

“Música popularesca”, concept, Mário de Andrade. 

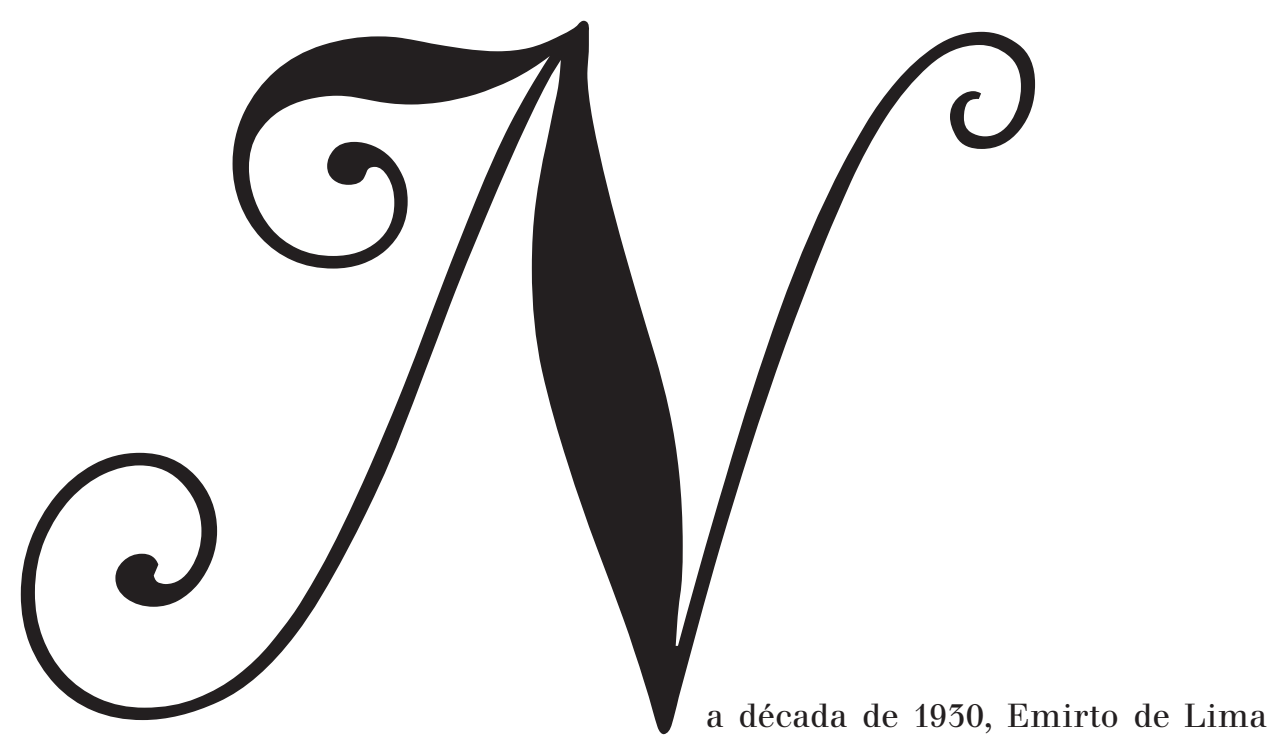

(1890 - 1972) quis diferenciar claramente dois tipos de música popular que circulavam no norte da Colômbia. Este compositor e pesquisador colombo--curacenho qualificou com o termo "populachera" a certa música popular que causava furor mas que não era a "verdadera música popular":

La mayoría de las gentes creen que la música ligera es la música verdaderamente popular. Hay, desde luego, mucha música ligera que ha obtenido la popularidad fácilmente, pero que dista muy lejos de ser la pura expresión del pueblo. Es necesario establecer la diferencia entre una y otra. La primera es populachera, música de cabaret, de los dancings, degenerada, sensual, trivial y frecuentemente vulgar. En tanto que la otra, la verdadera música popular trae consigo todos los perfumes de los campos, la evocación de las escenas hogareñas entre los humildes $[\ldots]^{3}$.

As canções “Compaegallo, Yo no le dije ná, Te lo vi, y otras músicas de pésimo gusto" foram exemplos, citados pelo autor, dessa música populachera. Acredita-se que as três peças foram difundidas por meio de discos de 78 rotações e de estações de rádio comerciais. A primeira, a guaracha "Cuidadito compay gallo", do músico cubano Antonio Fernandez (Ñico Saquito), tudo indica que teve algum êxito comercial porque foi gravada pela Columbia em 1936 e, no ano seguinte, por

3 LIMA, Emirto de. Folklore colombiano. Barranquilla: s.e., 1942. p. 152-153 (grifos nossos).

4. Idem, ibidem, p. 153 . 
Discos Victor $(\delta)^{5}$. A segunda, "Yo no le dije ná", o bolero do porto-riquenho Rafael Hernandez (O Jibarito), foi gravado em Nova Iorque por Discos Victor em $1935(\delta)^{6}$. E a terceira, "Te lo vi”, um son composto pelo panamenho Ricardo Fábrega, foi gravado por Discos Victor em 1934, em Nova Iorque. Essas três obras tinham em comum o fato de serem gêneros caribenhos de compositores estrangeiros; terem sido difundidas pelas maiores companhias discográficas norte-americanas presentes no mercado latino-americano, e terem sido peças de gêneros musicais vinculados às culturas urbanas nascentes. É provável que a principal causa da desaprovação expressada por Emirto de Lima se devesse não à qualidade musical das canções, e sim ao posicionamento do autor, filiado ao nacionalismo musical em voga. Tal corrente baseava-se num conceito de música popular de caráter romântico, contrário, por tanto, aos fenômenos urbanos e modernos.

Na América Latina, o interesse pelo estudo da música popular urbana, de um ponto de vista acadêmico, é uma das características da historiografia musical mais recente. $\mathrm{Na}$ atualidade, há consenso em afirmar que, na primeira metade do século XX, a música popular das cidades, que circulava nos discos e na rádio, não era considerada detentora de valores estéticos nem sociais que a tornassem um objeto de estudo interessante para os intelectuais do momento. Como exemplo desse desprezo, costumase lembrar do uso de termos como "populachera" e as posturas de músicos e pesquisadores como a exposta por Emirto de Lima.

Não obstante, é importante considerar que a música popular urbana ocupava cada vez mais lugares importantes nos cenários e nos meios elétricos de difusão e é pouco provável que se mantivesse afastada dos ouvidos dos acadêmicos. No caso brasileiro, há indícios de que certa elite intelectual a tenha desfrutado em seus saraus musicais, nos quais gêneros como o samba foram cantados e aplaudidos ${ }^{7}$.

No Brasil, o termo "música popularesca" foi utilizado por pesquisadores a partir da década de 1930, como equivalente ao hispano "música populachera". Este artigo estuda o uso desse termo na obra musical de Mário de Andrade, a quem a historiografia comumente atribui certo

5 As gravações em discos de 78 rotações podem ser escutadas no site http://memoriadamusica.com.br/site/sonoridades e serão destacadas no artigo com uma colcheia ( () . "Cuidadito compay gallo". Son interpretado por Panchito Riset e Quarteto Caney, Discos Columbia n. 5514-X, de autoria de Antonio Fernandez (Ñico Saquito), gravado em 1936, em Nova Iorque.

6 "Yo no le dije ná". Bolero interpretado por Grupo Victoria y Pedro Ortíz-Dávila, Discos Victor n. 32522, de autoria de Rafael Hernandez (El Jibarito), gravado em 1935 em Nova Iorque.

7 VIANA, Hermano. O mistério do samba. Rio de Janeiro: Jorge Zahar Editor, 1999. 
desprezo pela música popular urbana. Ainda que Emirto de Lima se correspondesse com Mário de Andrade e conhecesse trabalhos do pesquisador brasileiro, o caráter pejorativo de "populachera" não parece derivar do termo "popularesca", usado pelo brasileiro. Sem pretender criar uma relação etimológica entre os dois termos, o que se quer assinalar é o fato de que o surgimento da música popular urbana midiática trouxe mudanças no vocabulário e pensamento musicais de diversas regiões do continente latino-americano.

\section{Submúsica ou música popularesca?}

Quando Mário de Andrade vivia no Rio de Janeiro e esteve mais perto do surgimento do samba como música nacional - pelas mãos da indústria discográfica e da elite intelectual e política ${ }^{8}$-, qualificou como "submúsica" as canções lançadas para o carnaval carioca de 1939, com uma frase famosa, por seu teor particularmente agressivo: "trata-se exatamente de uma submúsica, carne para alimento de rádios e discos, elementos de namoro e interesse comercial, com que fábricas, empresas e cantores se sustentam [...]"9. Como se verá, estas palavras têm sido citadas inúmeras vezes pela historiografia posterior para demonstrar o desprezo que Mário de Andrade sentia pela música gravada.

Curiosamente, ao se voltar sobre a obra publicada do autor, observou-se que nem sempre os termos "submúsica" e "popularesco" foram equivalentes. O qualificativo "submúsica", com uma maior carga pejorativa, foi usado não só para a música gravada, mas também, em geral, para "esse gênero que consegue o aplauso fácil das pessoas fáceis"10. Segundo Mário de Andrade, a submúsica surgia em duas situações: quando a música gravada adotava soluções fáceis para se tornar comercial e quando a música erudita confundia virtuosismo com musicalidade e se tornava espetáculo circense ${ }^{11}$. Isso significaria que ao chamar de "submúsica" certa música gravada, o autor não partia de um preconceito em torno dos fenômenos midiáticos.

8 Idem, ibidem.

9 ANDRADE, Mário de. Música popular [1939]. In: ALVARENGA, Oneyda (org.). Música, doce música. Estudos da crítica e folclore. São Paulo: Livraria Martins Editora, 1976. p. 281 .

10 Idem. Nacionalismo musical [1939]. In: ALVARENGA, Oneyda (org.), op. cit., p. 296.

11 Sobre o tema do virtuosismo e as críticas que Mário de Andrade fazia ao "facilismo" na música acadêmica, ver suas resenhas de concertos. 
Uma pista sugestiva do som que pôde ter essa submúsica, no âmbito da música popular, encontra-se em sua coleção particular de discos. A capa do disco em que foi gravado o samba "Mulambo", interpretado por Sílvio Caldas ${ }^{12}$, tem a seguinte anotação, feita a mão pelo escritor: “[...] coisas como estas que aliás são ótimas pra quando precisar citar porcarias absolutas" $(\delta)^{13}$. Ao se ouvir o exemplo, não são evidentes os defeitos que desgostaram o musicólogo, porém, supõe-se que se relacionassem ao uso de fórmulas rítmicas, harmônicas e formais, comuns à música gravada na época. Talvez "Mulambo" tenha sido um samba classificado como submúsica, devido ao uso de fórmulas bem-sucedidas a fim de ganhar o "aplauso fácil".

Vale indagar: como então o valor pejorativo de "submúsica" teria se transferido para o termo "popularesco"? Longe do uso que Mário de Andrade fez da palavra "submúsica" - poucas vezes utilizada - é notório que, com o passar dos anos, o musicólogo fez críticas cada vez mais fortes à música e aos músicos que o rodeavam, tanto do meio popular quanto do meio erudito. Por exemplo, no início da década de 1940, quando sua maior preocupação era o compromisso social da arte, leem-se críticas como a feita à música dos meios de comunicação ao cotejá-la à música de Chiquinha Gonzaga: “[...] ela pertence a um tempo em que mesmo a composição popularesca, mesmo a música de dança e das revistas de ano ainda não se degradaram cinicamente, procurando favorecer apenas os instintos e sensualidades mais reles do público urbano de hoje"14.

Opiniões como a anterior foram lidas por outros estudiosos da música popular e, em geral, posteriores a Mário de Andrade, para justificar o profundo desprezo que merecia a música popular urbana. É possível que a fortuna crítica acabasse por transpor toda a carga pejorativa da categoria "submúsica" para o termo "popularesca", usado também pelo autor, tentando assim resolver as tenções sociais de seu próprio tempo.

A historiografia musical costuma afirmar que o interesse de Mário de Andrade pelo popular restringiu-se à música rural, longe dos processos de modernização, e a alguns gêneros urbanos, como a modinha e o maxixe. Conclui-se, habitualmente, que ele desprezou a música difundida pelos meios de comunicação da época e se assume que o termo "popularesca" denominava pejorativamente esse tipo de música. Não obstante, a leitura

12 "Mulambo". Samba interpretado por Silvio Caldas, discos Victor $\mathrm{N}^{\circ} 333^{01}$, de autoria de Carlos Cardoso, gravado em $193^{\circ}$.

13 Catálogo Discos Mário de Andrade, Arquivo do Instituto de Estudos Brasileiros. Disponível em: <www.ieb.usp.br/catalogo\%5Feletronico> . Acesso em: 13 out. 2013.

14 ANDRADE, Mário de. Chiquinha Gonzaga [1940]. In: ALVARENGA, Oneyda (org.), op. cit., p. 331 . 
cuidadosa de parte de sua obra indicou que o significado desse termo nem sempre foi o mesmo, alterando-se ao longo do tempo e à medida que os fenômenos culturais desenvolveram-se, como se verá mais adiante.

Em 1988, o historiador Arnaldo Contier entendeu a expressão “música popularesca” na obra de Mário de Andrade como música popular urbana usada para consumo imediato e oposta ao popularfolclórico ${ }^{15}$. Em síntese, essa tem sido a principal interpretação dada ao termo pela historiografia. Contier é um dos historiadores mais influentes na atual historiografia musical brasileira, e sua percepção do sentido pejorativo de "popularesco" foi argumentada convincentemente por intermédio da reconstrução histórica do contexto social e político em que Mário de Andrade viveu ${ }^{16}$. De um ponto de vista historiográfico, a leitura de Contier auxiliou a explicação do abandono sofrida pela música popular urbana por parte da academia brasileira durante grande parte do século XX. O fato de ter sido marginalizada por um dos intelectuais mais importantes da primeira metade do século $\mathrm{XX}$ explicaria que a academia posterior se mantivesse receosa em relação ao tema ${ }^{17}$.

Por outro lado, tudo parece indicar que as leituras indiretas da obra de Mário de Andrade deram continuidade à interpretação proposta por Contier. Outros autores um pouco anteriores a Contier, como Vasco Mariz e Renato de Almeida, utilizaram em seus escritos a expressão "música popularesca" com a intenção de menosprezar a música urbana midiatizada ${ }^{18}$ e, talvez por isso, não surpreendesse aos leitores de finais do século XX o uso da expressão ilustrada por Contier.

Um exemplo dos mal-entendidos acerca do pensamento musical de Andrade é a citação de suas palavras a respeito da música popular urbana como "carne para alimento de rádios e discos". Entre outros autores, Sean Stroud e Márcio de Souza a utilizaram para exemplificar o menosprezo de Mário de Andrade pelo fenômeno. Ambos os autores afirmaram que essas palavras teriam sido pronunciadas pelo escritor em uma conferência de 1934, quando, na realidade, foram escritas em um artigo de $1939^{19}$. A

15 CONTIER, Arnaldo D. Brasil Novo. Música, nação e modernidade: os anos 20 e $z_{0}$. 1988. 805 f. 2 v. Tese (Livre-docência em História Social) - Faculdade de Filosofia, Letras e Ciências Humanas, Universidade de São Paulo, 1988. p. 536.

16 Idem, ibidem, p. 171.

17 MORAES, José Geraldo Vinci de. "Samba tem cadência. Digo a verdade. E até já chegou na universidade”. In: DAMASCENO, Francisco José Gomes (org.). Experiências musicais. Fortaleza: Prefeitura Municipal de Fortaleza/EDUECE, 20o8. p. 30-z1.

18 Por exemplo, ver: ALMEIDA, Renato. Música folclórica e música popular. Boletim da Comissão Gaúcha de Folclore, v. 22, p. 8, 1958.

19 STROUD, Sean. The Defence of Tradition in Brazilian Popular Music: politics, culture, and the creation of música popular brasileira. Aldershot/Burlington, Ashgate Publishing Company, 20o8. p. 13; SOUZA, Márcio de. Mágoas do violão: mediações 
inexatidão da sua citação se deve ao fato que tanto Stroud quanto Souza não conheceram o artigo original de Mário de Andrade, mas tomaram a citação e sua interpretação do livro O violão azul: modernismo e música popular, de Santuza Cambraia $\operatorname{Naves}^{20}$. Por sua vez, Santuza Cambraia Naves tampouco leu o original de Mário de Andrade, mas tomou a informação da resenha que Vasco Mariz fez sobre a vida e obra do autor, em $1983^{21}$. A leitura do texto de Mariz evidencia a falta de dados bibliográficos quanto à citação e a interpretação conveniente dada às palavras do famoso intelectual. Graças à comparação sugestiva que Mariz fez entre a música de rádio da época de Andrade e o consumo televisivo de sua própria época, pode-se dizer que sua citação procurava denunciar a baixa qualidade da música difundida pelos meios de comunicação, especialmente pela televisão, e não o pensamento de Mário de Andrade. Na história das ciências, é comum esse tipo de argumentação que põe na boca de autores mortos e de amplo reconhecimento acadêmico posturas polêmicas contemporâneas para tentar resolver tensões que não faziam parte de seu tempo.

A excessiva prevenção atribuída a Mário de Andrade contra a música popular urbana e midiática tem bases históricas que remontam aos inícios do século XX. Independentemente das apreciações de nosso autor, é sabido que a nova música incomodou por diversos motivos uma parcela da população nas cidades. Como bem ilustrou Camila Koshiba Gonçalves, desde a década de 1920, surgiram críticas e inconformismo quanto aos sons de gramofones e rádios nas ruas das cidades brasileiras. Tanto no Rio de Janeiro quanto em São Paulo, criticou-se o alto volume dos aparelhos, que contribuíam para o barulho das cidades. Na opinião da autora, essas denúncias também se relacionavam ao menosprezo que alguns jornalistas expressaram pela música "desprovida de harmonia, barulhenta, impregnada de percussões violentas, de dissonâncias estranhas" que "encontra uma larga e vasta aceitação", segundo palavras de um dos comentaristas da Phono-Arte em 1930².

culturais na música de Octávio Dutra (Porto Alegre, 1900-1935). 2010. 224f. Tese (Doutorado em História) - Faculdade de Filosofia e Ciências Humanas, PUCRS, 2010. p. 32 .

20 NAVES, Santuza Cambraia. O violão azul: modernismo e música popular. Rio de Janeiro: Editora FGV, 1998. p. 48.

21 MARIZ, Vasco. Três musicólogos brasileiros. Mário de Andrade, Renato Almeida, Luiz Heitor Corrêa de Azevedo. Rio de Janeiro: Civilização Brasileira/Brasília: Instituto Nacional do Livro, 1983. p. 43.

22 Amplificações e sonoridades. Phono-Arte, n. 15, 15 jan. 1930 apud GONÇALVES, Camila Koshiba. Música em 78 rotações: "Discos a todos os preços" na São Paulo dos anos 30. 2006. $23_{2}$ f. Dissertação (Mestrado em História Social) - Faculdade de Filosofia, Letras e Ciências Humanas, Universidade de São Paulo, 20o6. p. 125. 
Para se compreender melhor esse sentimento de prevenção em relação à nova música, recorde-se que uma das características da visão de mundo romântica foi seu temor e crítica à quantificação do mundo ou "envenenamento da vida social pelo dinheiro", entre outros aspectos ${ }^{23}$. No mundo musical, essa crítica tomou forma ao menosprezar a música feita para ser vendida, principalmente aquela dirigida ao crescente público amador que procurava diversão. Embora esse não tenha sido um fenômeno próprio do século XX, pois já no século anterior deu-se a comercialização de música fácil em partituras soltas, esse parâmetro foi continuado pela empresa discográfica, ávida de lucros comerciais, e as denúncias relativas a essa situação não tardaram.

Tanto o desprezo à relação entre criação musical e mercado quanto a prevenção contra os meios mecânicos de reprodução do som alimentaram a ideia de que a música urbana era inferior e desprezível, por trazer dentro de si o dinheiro e a máquina, duas particularidades reprováveis da modernidade capitalista, segundo a visão romântica.

\section{O popularesco e o vulgar na década de 1930}

É difícil definir se a expressão "música popularesca” foi cunhada por Mário de Andrade ou por algum outro autor. Na literatura brasileira consultada não se encontraram escritos anteriores que a utilizassem. Haveria, contudo a possibilidade de que Mário de Andrade tivesse adotado o termo de um de seus mais interessantes colegas europeus, Béla Bartók ${ }^{24}$.

De acordo com o etnomusicólogo Marco Lutzu, na tradução para o italiano do artigo de Bartók, “Mi a népzene” [O que é a música popular?], publicado originalmente em 1931, foi usada a expressão "música popularesca" ".5 . Na tradução espanhola do mesmo artigo, o adjetivo "popularesco" também foi usado para se referir à "música popular ciudadana".

Podemos llamar música popular ciudadana o música culta popularesca, a aquellas melodías de estructuras más bien simples, compuestas por autores dilettantes pertenecientes a la clase burguesa y, por ello, difundidas sobre todo en la clase burguesa. Esas melodías, en cambio, no son conocidas por la clase campesina

23 LÖWY, Michael; SAYRE, Robert. Revolta e melancolia. O romantismo na contramão da modernidade. Petrópolis: Vozes, 1995.

24. Agradeço as conversas com a professora Flávia Camargo Toni a respeito.

25 Comunicação pessoal (Havana, 4 de novembro de 2010) e correio eletrônico (17 de novembro de 2010). 
o, a lo sumo, han penetrado en ella sólo relativamente tarde y siempre a través de la "mediación" de la burguesía. ${ }^{26}$

Nesse artigo, Bartok atribuiu um valor "incomparavelmente superior" à música das aldeias camponesas em relação à música culta popularesca, porque a música camponesa "no es, en el fondo, otra cosa que el producto de una elaboración cumplida por un instinto que actúa inconscientemente en los individuos no influidos por la cultura ciudadana" ${ }^{27}$.

Pode-se dizer que Mário de Andrade conheceu uma pequena parte do trabalho do músico húngaro graças a uma papeleta de seu "fichário analítico", na qual fez referência ao artigo "La musique populaire hongroise", publicado em La revue musicale, de 1921. Nesse escrito, anterior em dez anos ao artigo "Mi a népzene", Béla Bartók usou a palavra francesa "semi -populaire", que se traduziria literalmente como "semipopular", para explicar os tipos de música existentes entre os camponeses de seu país:

D'autre part, on peut très bien compter au nombre des mélodies dites popularies certaines mélodies semi-populaires d'amateurs, chantées non pas par quelques individus, mais dans toute la classe des paysans, et cela pendant une période de temps plus ou moins longue. ${ }^{28}$

Mais adiante, Bartók explicou, a respeito dessa música semi-populaire, que:

On aime souvent à confondre les mélodies populaires proprement dites avec les mélodies semi-populaires d'amateurs. Les auteurs de ces dernières disposent d'une certaine culture musicale, importée, en général, de la ville; ce sont, pour la plupart, des musiciens dilettantes; aussi, dans les mélodies de leur cru, mêlent-ils certains lieux communs occidentaux à certaines particularités exotiques de leur propre musique populaire. ${ }^{29}$

26 RASCHELLA, Roberto (org.). Escritos sobre música popular. México: Siglo XXI, 1985. p. 66 (grifos nossos).

27 BARTÓK, BÉLA. ¿Qué es la música popular? [1931]. In: RASCHELLA, Roberto (org.), op. cit., p. 68.

28 Idem. La musique populaire hongroise. La revue musicale, ano 2, n. 1, p. 10, 1921 (grifos nossos).

29 Idem, ibidem. 
Embora seja difícil mensurar o impacto de tal escrito no pensamento do musicólogo brasileiro, acredita-se que sua leitura não foi paradigmática, dadas as poucas notas marginais que deixou em seu exemplar. Tampouco é possível afirmar que Mário de Andrade tenha tomado e traduzido "semi-populaire" como "popularesco", pois, para um escritor como ele, com grandes dotes literários e um manejo criativo do idioma, não seria difícil cunhar a palavra por si mesmo. Além disso, se Mário de Andrade leu o artigo de Béla Bartók próximo ao ano de publicação (1921), teriam se passado quase dez anos entre sua leitura e a utilização da expressão "música popularesca", pois se presume que foi a partir 1931 que ele começou a usá-la de forma ocasional.

Nos primeiros anos da década de 1930, o adjetivo "popularesco" foi usado nas resenhas jornalísticas que Mário de Andrade escreveu acerca dos concertos de música erudita aos quais assistiu em São Paulo. Nelas, o autor usou a palavra supracitada para descrever o que seus ouvidos escutaram, esforçando-se por levar os sons musicais às páginas do jornal. Nesse contexto, observou-se que o escritor empregou "popularesco" quando julgou que, na música interpretada, havia algo proveniente ou também utilizado na música popular, o que deve tê-lo agradado, tendo em vista seu interesse pessoal em aproximar o popular e o erudito. Nestas resenhas "popularesco" teve um uso descritivo e não depreciativo.

Em 1931, por exemplo, ele qualificou como popularescos os elementos musicais herdados do romantismo por uma geração de compositores brasileiros, entre os quais encontrava-se Henrique Oswald ${ }^{30}$. Dois anos depois, nas resenhas dos recitais da cantora Vera Janacopulos e do Quarteto Aguilar, chamou de popularescas duas obras do compositor hispano-cubano Joaquin Nin y Castellanos, "Da Murcia", que considerou "admirável de beleza linear e originalidade rítmica" æ11, e outra, cujo título não mencionou ${ }^{32}$. O mesmo termo foi usado em outra resenha para adjetivar uma das Novas sonatinas do francês Charles Koechlin, particularmente o "deliciosíssimo final, ronda popularesca que está entre as melhores coisas que Koechlin escreveu", tocada ao piano por Lavínia Viotti ${ }^{5}$. Também considerou como popularescos o allegro con brio de uma sonata de Felice de Giardini, tocado por orquestra de cordas sob direção de Leon Kaniefsky ${ }^{34}$, e a interpretação feita pela pianista Guiomar

3o ANDRADE, Mário de. Herinque Oswald [1931]. In: ALVARENGA, Oneyda, op. cit., p. 168.

31 Idem. Quarteto Aguilar [1933]. In: CASTAGNA, Paulo (org.). Música e jornalismo: Diário de S. Paulo. São Paulo: Edusp/Hucitec, 1993, p. 27.

32 Idem. Vera Janacopulos [1933]. In CASTAGNA, Paulo (org.) op. cit., p. 59.

33 Idem. Lavínia Viotti [1933]. In CASTAGNA, Paulo (org.) op. cit., p. 31.

34 Idem. Orquestra de cordas [1933]. In CASTAGNA, Paulo (org.) op. cit., p. 55. 
Novais de uma sonata de Scarlatti, no momento em que "chegou a sons dum napolitanado popularesco, de infinito sabor"35.

Quando Mário de Andrade usou o termo "popularesco", suspeitase que o autor estaria denominando elementos musicais mais sutis que os recursos usados no arranjo musical, o que sabia diferenciar muito bem. Na resenha sobre o concerto da cantora Julieta Teles de Meneses, o escritor esclareceu que no programa havia "peças populares harmonizadas", nas quais a cantora manteve um "equilíbrio delicioso entre o canto popular e a interpretação erudita, sem deformar coisíssima nenhuma"3̄. Também, por ocasião de um dos concertos da Sociedade de Cultura Artística, Mário de Andrade escreveu que as canções dos compositores Chaga Júnior e Mário Monteiro foram feitas sobre motivos populares portugueses e harmonizadas pelos músicos ${ }^{37}$. Nos dois exemplos, pode-se observar que Mário de Andrade não denominou essas harmonizações como obras popularescas, reservando o adjetivo para outro tipo de música.

Em 1941, em um de seus artigos a respeito das mudanças da modinha, Mário de Andrade voltou a usar o termo "popularesco", talvez procurando criar um ponto médio entre a música folclórica e a música erudita. Acerca da existência de peças religiosas eruditas nas tradições camponesas, o musicólogo anotou que elas tinham sido "impostas ao povo pela classe eclesiástica - peças sabidamente de autor -, e que, como peças, quase nunca conseguem se popularizar folcloricamente. Tipo de fato popularesco, mas não exatamente popular"38. Assim, assinalou que algumas peças religiosas, embora impregnadas pelo caráter popular, não se transformaram em música folclórica, mas mantiveram seu estilo original e, consequentemente, acabaram pertencendo a um mundo intermediário entre o erudito e o popular.

Por outro lado, chama a atenção o fato de que Mário de Andrade usou, em várias ocasiões, a palavra "vulgar" próximo a "popularesco", como se elas estivessem relacionadas, mas se suspeita que isto se deva a um significado particular que o autor também atribuiu a "vulgar" 59 . Em 1935, em uma resenha de um dos concertos do violinista Fritz Kreisler, ele esclareceu que o adjetivo "popularesco" não tinha um caráter vulgar. A palavra "vulgar" foi explicada por Andrade no mesmo artigo, como "um não-sei-quê de asperidade de sentir, de esquecimento da cultura,

35 Idem. Guiomar Novais [1933]. In: CASTAGNA, Paulo (org.) op. cit., p. 60.

$3^{6}$ Idem. Cultura artística: Julieta Teles de Meneses [1934]. In CASTAGNA, Paulo (org.) op. cit., p. 252.

37 Idem. Cultura artística [1934]. In: CASTAGNA, Paulo (org.) op. cit., p. 137.

38 Idem. A modinha e Lalo [1941]. In: ALVARENGA, Oneyda, op. cit., p. 343.

39 Agradeço as conversações com a musicóloga Luciana Barongeno a respeito. 
quase de tosquidão. É uma grande ausência de malícia, essa castalia da arte" ${ }^{40}$. Tal elucidação foi feita para explicar a que se referia quando dizia que a Chaconne de Bach, tocada naquela noite, era "popularesca" mas não era "vulgar", vulgar no sentido dado por ele mesmo à palavra.

Talvez, para o musicólogo, "vulgar" apresentava um sentido, em certa medida, positivo, pois em um artigo em que se referiu à música de José Barbosa da Silva (Sinhô), quando passou por São Paulo em 1929, disse que o músico conservava dos cariocas:

[...] aquele riso da experiência divertida, aquela leveza de borboleta, ingenuidade originalíssima, esperteza defensiva que só mesmo os índios, as crianças e... os cariocas possuem. E a sensualidade.

Quem for escutar Sinhô perceberá tudo isso nos poemas cantados que ele inventa. É possível que percebam também a banalidade na obra dele. Banalidade não. Vulgaridades, as quais serão banalidades apenas pros indivíduos que não sabem reaprender todos os dias, certos fenômenos, certas reações essenciais do "rei dos animais" diante do amor, da pândega e da sociedade. ${ }^{41}$

Nota-se, por este depoimento, que Mário de Andrade entendia "vulgaridade" como um aspecto quase positivo e "banalidade" como algo nocivo. Dentre a correspondência do escritor, conservou-se um cartão enviado por Sinhô, no qual "Cumprimenta e agradece o seu valioso auxílio em prol de sua festa a realizar-se em 19.5.1929 no Theatro Municipal", no qual se deduz que Mário de Andrade mostrou alguma simpatia pelo músico carioca ${ }^{42}$.

Dez anos após a visita do músico a São Paulo, Mário de Andrade voltou ao significado da palavra "vulgar" quando usou novamente este adjetivo no prefácio do livro Shostakovich. Na ocasião, advertiu que aplicava seu significado etimológico para chamar a música que era "fácil de apreensão e direta de efeito". Nesse escrito, caracterizou a obra de Shostakovich por ter uma "vulgaridade popularesca" ${ }^{43}$, referindo-se às melodias

40 ANDRADE, Mário de. Kreisler [1935]. In: Idem. CASTAGNA, Paulo (org.), op. cit., p. 3o6.

41 Id., Taxi: Sinhô [1929]. In: LOPEZ, Telé Ancona (org.). Taxi e Crônicas no Diário Nacional. São Paulo: Duas Cidades/Secretaria da Cultura, Ciência e Tecnologia, 1976. p. 104.

42 Cartão de Sinhô para Mário de Andrade. Arquivo do Instituto de Estudos Brasileiros, Fundo Mário de Andrade, Correspondência passiva. MA-C-CPL648o, s.d.

43 ANDRADE, Mário de. Shostacovich [1945]. In: COLI, Jorge (org.). Música final. Mário de Andrade e sua coluna jornalística Mundo Musical. São Paulo: Editora da Unicamp, 1998. p. 4 o6. 
feitas “à feição popular" ${ }^{44}$, que serviam para tornar sua música comprensível ao público proletário. No mesmo documento, Mário de Andrade explicita que o contrário a vulgar seria banal, e especificou que,

Na verdade, não se pode atribuir banalidade à música folclórica, e só mesmo com muita reserva à música popularesca urbana, que serve para o gasto transitório da coletividade. Seria adotar um critério crítico individualista e hedonístico para um fenômeno do quotidiano utilitário. Mas de fato o produto folclórico mesmo diante dum crítico estética, jamais é banal. A música folclórica é fácil, mas não banal. Pode ser vulgar, mas não banal ${ }^{45}$.

Embora o estudo dos conceitos "vulgar" e "banal" requeira uma análise do pensamento estético de Mário de Andrade, por ora se pode assinalar que, no fim da vida, o autor qualificou como "vulgares" a música popular urbana e folclórica, ressaltando-se que o seu uso do adjetivo "vulgar" não possuía a carga depreciativa com que habitualmente se usava a palavra, mas sim um tom benéfico que despertava simpatia no autor, "um não-sei-quê de asperidade de sentir, de esquecimento da cultura, quase de tosquidão", como definiu em 1935.

\section{Os discos popularescos}

Depois da passagem de Mário de Andrade pelo Departamento de Cultura, e já na década de 1940, o escritor usou o adjetivo "popularesco" para qualificar certo repertório que circulava nos meios de comunicação elétricos, e não somente algumas peças do repertório erudito. De fato, foi em 1940, quando usou a expressão “discos popularescos" para caracterizar o repertório fonográfico que circulava pelas cidades ${ }^{46}$.

Embora os escritos publicados de Mário de Andrade não se referissem diretamente à discografia como fenômeno em si, conta-se com um curto manuscrito inacabado, cujo título reza "O disco e a música popular no Brasil”. A emenda no título parece indicar que começou como um texto que relacionaria os discos com a música popular, mas que, em certo momento, seu autor preferiu adjetivar como "populares" os próprios discos, como se tentasse se referir a uma popularização do disco. Nesse manuscrito,

4.4 Idem, ibidem, p. 40o.

4.5 Idem, ibidem, p. 4,01.

46 ANDRADE, Mário de. Camargo Guarnieri [1940]. In: ALVARENGA, Oneyda, op. cit., p. 327 . 
elaborado provavelmente em meados da década de 1930, o autor aparenta estar propenso a criar uma argumentação em torno do tema da discografia brasileira para justificar ou motivar a criação da Discoteca Pública ${ }^{47}$.

Intui-se que, ao escrever este esboço, Mário de Andrade percebeu que circulavam dois tipos de música popular nas gravações discográficas. Um que lhe seria mais familiar porque provinha das tradições musicais camponesas e étnicas, que ele e pesquisadores do folclore vinham estudando, e que chamavam "música folclórica" ou "popular". O outro, possivelmente, possuía outra sonoridade, parcialmente nova, a qual Mário de Andrade reconhecia como um tipo de música banhada em uma atmosfera estranha, relacionada aos fins comerciais das empresas discográficas, e também chamada de "música popular".

É possível que, para Mário de Andrade, fosse necessário distinguir basicamente entre discos de música popular comerciais e discos científicos. De forma clara e repetida, o autor destacou a importância de gravar música e reproduzi-la sem que os sons mudassem drasticamente, de modo que o pesquisador pudesse estudá-la em seu gabinete. Estes seriam os discos de caráter científico, quer dizer, aqueles que reproduziam a música popular o mais próximo possível de como era tocada em seu contexto. Para Andrade, tais discos representavam uma ferramenta fundamental de pesquisa porque a música era um fenômeno volátil do qual a grafia ocidental não conseguia dar conta.

Em suas anotações, Mário de Andrade usou o adjetivo “científico" para caracterizar alguns dos discos de música brasileira de sua coleção, como as gravações das peças "Toada de mutirão", de autor desconhecido $(\delta)^{48}$, e "Folia de Reis", de Angelino de Oliveira, interpretada por Cornélio Pires, Maracajá e Os Bandeirantes em $1930(\delta)^{49}$. Na capa do último disco, lê-se:

Um dos poucos discos folcloricamente científicos que possuímos, afora as Modas caipiras. A Folia é absolutamente sem influência ou arranjo. Por azar, não havia no agrupamento orquestral desta Folia, o triângulo, o "ferrinho" como eles dizem, lembrando Portugal, que é obrigatória das orquestrinhas das Folias, conforme me informou o próprio Cornélio Pires ${ }^{50}$.

47 ANDRADE, Mário de. O disco popular no Brasil. Arquivo do Instituto de Estudos Brasileiros, Fundo Mário de Andrade, Série Manuscritos, Caixa 057, MA-MMA-o4o, s.d.

48 “Toada de mutirão", interpretado por Cornélio Pires com Zé Messias e Parceiros, Discos Columbia n. 20033, gravado em 1930.

49 “Folia de Reis”, interpretado por Cornélio Pires e Foliões de Zé Messias, Discos Columbia n. 20032, de autoria de Angelino de Oliveira, gravado em $193^{\circ}$.

$5^{\circ}$ Catálogo Discos Mário de Andrade, op. cit. 
Mário de Andrade também reconhecia que havia outros discos de música popular produzidos com o fim de agradar e ser vendidos rapidamente. Tratava-se, segundo o autor, de discos despreocupados com um fiel registro das tradições musicais, mas que acomodavam os gêneros populares a outras circunstâncias, como as particularidades técnicas do processo de gravação, o orçamento disponível para o pagamento de músicos, ou qualquer outro parâmetro alheio a um interesse "científico". De acordo com o manuscrito supracitado, pode-se dizer que o musicólogo atribuía tal circunstância ao desconhecimento das tradições musicais populares do Brasil e a certo menosprezo das empresas estrangeiras por elas. Duas particularidades que seriam as causas de que as gravações comerciais transformassem os elementos musicais tradicionais sem os critérios apropriados.

Talvez, na opinião do autor, a existência de dois tipos de discos de música popular - científico e comercial - não impedia ao pesquisador musical de usar alguns dos produtos das empresas fonográficas estrangeiras. Discos comerciais que podiam ser usados na pesquisa eram, por exemplo, aqueles que reproduziam gêneros como a moda caipira, alguns de feitiçaria carioca ou relacionados com a música da África, pois eram gêneros "infensos à influência universalista das cidades" ${ }^{51}$. Na capa do disco gravado pela Odeon, com os cantos de Echu e Ogum, interpretados pelo Conjunto Africano e Getúlio Marinho $(\delta)^{52}$, o escritor apontou: "Disco ótimo. De originalidade formidável. Parece cientificamente perfeito" ${ }^{53}$.

Também recomendava usar, no estudo musicológico, os discos de gêneros nascidos da "influência universalista das cidades", como era o caso do choro e do maxixe no Brasil, e do huayno na Bolívia. Entre os discos de sua coleção estão os huaynos "Amorosa palomita" e "Delícias del Inca", interpretados por Felipe V. Rivera e sua Orquestra típica boliviana $^{54}$, e os choros "Carinhoso", de Pixinguinha (§), e "Suspiros", de Gerald Desmond, gravados pela Discos Victor em 1929 ("Choros muito bons. Alfredo Vianna é Pixinguinha"55) $(\delta)^{56}$.

51 ANDRADE, Mário de. O disco popular no Brasil, op. cit.

$5^{2}$ "Canto de Echu". Macumba interpretada por Getúlio Marinho e Conjunto Africano, Discos Odeon n. 1069o, de autoria de Elói Antero Dias, gravado em 1931. "Canto de Ogum". Macumba interpretada por Getúlio Marinho e Conjunto Africano, Discos Odeon n. 1069o, de autoria de Elói Antero Dias, gravado em 1931. Catálogo Discos Mário de Andrade, op. cit.

54 Discos Victor n. 47682.

55 Idem.

56 "Carinhoso". Choro orquestral interpretado por Orquestra Victor Brasileira, Discos Victor n. 33209, de autoria de Alfredo da Rocha Vianna (Pixinguinha) e João de Barro (Braguinha), gravado em 1929."Suspiros". Choro orquestral interpretado por 
O terceiro caso, no qual os interesses do disco comercial coincidiriam com os interesses científicos, não aparece claramente referido na redação do manuscrito. Talvez, Mário de Andrade quisesse advertir que, em geral, os discos comerciais mantinham as características rítmicomelódicas da expressão popular, mas modificavam seu acompanhamento, instrumentação e caráter vocal. Portanto, o pesquisador poderia estudar somente os elementos rítmico-melódicos dos discos comerciais como elementos legítimos das tradições populares. Provavelmente, esses foram os discos que Mário de Andrade chamou “discos popularescos” em 1940.

Mário de Andrade não se equivocou ao identificar a melodia e o ritmo da música popular gravada como frequentemente inalterados. Segundo William Howland Kenney, na primeira década do século XX, nos Estados Unidos, quando a indústria fonográfica iniciou as gravações da chamada foreing music, os empresários notaram que no mercado de seu país, os adjetivos "de fora" e "imigrante" eram assimilados a situações de pobreza e sujeira. Para eludir essa situação, as casas de discos apresentaram a música estrangeira em um formato mais "limpo", e os gêneros folclóricos foram interpretados nas gravações por artistas de concerto e de ópera. Essa estratégia criou uma "síntese entre música pouco culta e interpretações eruditas", propiciando uma sonoridade simbiótica a algumas das peças musicais populares que se escutava nos discos. Após a Primeira Guerra Mundial, iniciou-se a regravação da música popular americana nos idiomas mais falados pelos imigrantes, além da produção da chamada música típica em traduções para o inglês. Este foi o primeiro passo para que as companhias descobrissem o êxito comercial da apropriação de repertórios típicos e sua apresentação em arranjos com instrumentação e idioma estadunidenses ${ }^{57}$.

Para obter uma noção sobre o tipo de música que os “discos popularescos" continham, é interessante notar que, em uma menção muito rápida em 1941, Mário de Andrade caracterizou com o termo "popularesco" a música das jazz-band "de nossos dias"58, gênero bem representado em sua coleção particular de discos. Quatro anos depois, em outro de seus escritos, o musicólogo usou como exemplos de música popularesca o samba "O que é que a bahiana tem", cantado por Carmen Miranda, e a canção cubana "O vendedor de amendoim”, os

Orquestra Victor Brasileira, Discos Victor n. 33209, de autoria de Gerald Desmond, gravado em 1929.

57 KENNEY, William Howland. The Phonograph and the Evolution of "Foreign" and "Ethnic" Records. Recorded Music in American Life: the Phonograph and Popular Memory, 1890-1945. Nova Iorque, Oxford University Press, 1999. p. 84.

$5^{8}$ ANDRADE, Mário de. A modinha e Lalo [1941]. In: ALVARENGA, Oneyda, op. cit. 
quais descreveu como "duas obra-primas. Música popularesca, apenas urbana e semierudita, extra folclórica, mas obras-primas"59. As duas peças encontram-se gravadas em discos de sua coleção. "O que é que a bahiana tem" foi gravado pelo selo Odeon em $1939(\delta)^{60}$, e "O vendedor de amendoim" apresenta duas versões, ambas da Discos Victor: uma com o título de "The Peanut Vendor" ( ()$^{61}$, à qual se referiu como versão "ianquecubana" ${ }^{\prime 2}$, e a outra interpretada pelo Trio Matamoros $(\delta)^{63}$, em cuja capa deixou escrito: "Um acompanhamento instrumental bem brasileiro..."

\section{A música popularesca nos anos 1940}

A única característica musical que Mário de Andrade atribuiu à música popularesca foi timidamente esboçada em seu artigo "Cândido Inácio da Silva e o lundu” (1945), quando parece defender que a música folclórica sempre possuía texto, ao passo que a música popularesca poderia não tê-lo: "não trazem textos - caráter distintivo da manifestação que não é folclórica, mas apenas popularesca e urbana"65. Com essa particularidade, talvez quisesse incluir a música instrumental a meio caminho entre o popular e o erudito, como é o caso do jazz.

Por outro lado, duas semanas antes de sua morte em 1945, foi publicado seu último artigo no periódico Folha da manhã, intitulado "Do meu diário", em que escrevia notas curtas sobre diversos temas. Nesse dia, o tema foi uma pequena reflexão acerca da natureza do popular e do popularesco. Mário de Andrade iniciou sua exposição afirmando que comumente se acreditava que o popular estava ligado ao tradicional e o popularesco à moda. Mas o autor notava que os fenômenos folclóricos (sinônimo de popular) não eram duradouros, poderiam ser esquecidos em pouco tempo, mas seus elementos básicos permaneciam

59 Idem. Música universitária [1944]. In: COLI, Jorge (org.), op. cit., p. 161.

6o "O que é a bahiana tem". Samba interpretado por Carmen Miranda, Discos Odeon n. 11710 , de autoria de Dorival Caymmi, gravado em 1939.

61 "The Peanut Vendor". Rumba fox-trot interpretado por Antonio Machin, Don Azpiazu e sua orquestra Casino Havana, Discos Victor n. 22483, de autoria de Moises Simons, gravado em 1929.

62 Catálogo Discos Mário de Andrade, op. cit.

63 "El manicero". Pregón-son interpretado por Trio Matamoros, Discos Victor n. 4,6401, de autoria de Moises Simons, gravado em 1930 em Nova Iorque.

64. Ibidem. Parece que Mário de Andrade propunha-se a exemplificar a transformação da rumba em fox-trot, usando como exemplo as duas gravações de "El manicero" existentes em sua coleção.

65 ANDRADE, Mário de. Cândido Inácio da Silva e o lundu [1945]. Latin American Music Review, v. 20, n. 2, 1999. 
na variação. Ao contrário, o popularesco implicava progresso, ou seja, transitoriedade, e passava rápido porque acompanhava a moda, ainda que não fosse raro a moda voltar e um tema musical popularesco ser ouvido novamente e exatamente igual, porque, se mudasse, correria o risco de não ser reconhecido. Mário de Andrade afirmava que o folclórico não precisava de um museu, devido à sua natureza antimuseológica, e que o popularesco, que não era considerado digno de museu, possuía uma natureza imutável, ou seja, museológica: “Quem toca um tango de Nazaré, lhe modificando parte da melodia está errado. Quem executar o Tutu Marambá, na variante de sua região, não está errado"66.

Nesse último escrito, Mário de Andrade partiu de uma espécie de acordo tácito a respeito da consideração do popularesco, enquanto relacionado à moda e detentor de escasso valor. Se o autor tinha dado a entender que popularesco era algo "feito à feição do popular", então, quem teria atribuído estas características depreciativas ao termo? Incomodava-se Mário de Andrade com essa "tergiversação"? Uma resposta responsável implicaria uma revisão detalhada das interpretações que seus colegas construíram sobre seus escritos e um estudo mais cuidadoso sobre sua relação com o musicólogo paulistano. Por ora, considera-se que tal tensão entre o termo "popularesco" como "feito à maneira popular", aparentemente neutro, e sua conotação depreciativa, é sintomática do conflito que se forjava entre a visão romântica do popular e a comercialização da música popular urbana em voga.

Na comparação entre o Compêndio da história da música, publicado em 1929, e a Pequena história da música, publicada em 1942, desta-se o fato de que, no capítulo a respeito da música brasileira, Andrade adicionou, na segunda edição, o termo "popularesca" para qualificar a poesia cantada por Catulo da Paixão Cearense ${ }^{67}$. A partir desta mudança, deduz-se que, em 1929, Mário de Andrade considerava a música difundida pela indústria fonográfica simplesmente música popular, mas que, treze anos depois, percebeu que estava diante de um músico que, na realidade, fazia um novo tipo de música.

Pode-se pensar que a mudança no ambiente musical, ocasionada pela radiodifusão e pela indústria discográfica tenha feito com que Mário de Andrade incrementasse o uso da expressão "música popularesca" para denominar esta nova música. Como afirmou Alberto Cavalcanti, Andrade fez a distinção entre o popular e o popularesco quando:

66 Idem. Do meu diário [1945]. In: COLI, Jorge, op. cit., p. 179.

67 Idem. Pequena história da música. [1942] São Paulo: Livraria Martins Editora, 1953. p. 193. 
Mário já dispunha de fenômeno consolidado de exploração da música de feitio popular - seja no rádio, seja no disco, ou ainda em novos espaços, como os filmes musicais e os cassinos - e já podia observar o modus operandi dos autores e intérpretes envolvidos na composição e execução musical afastando-se dos procedimentos mais espontâneos e ingênuos - ou mais tradicionais e oitocentistas - do período anterior. ${ }^{68}$

As mudanças que a radiodifusão e a empresa discográfica trouxeram refletiram-se na configuração paulatina de um repertório com particularidades musicais próprias. Despontava assim uma sonoridade nova na música gravada, que inicialmente estava relacionada com as características técnicas do processo de gravação, e que terminaram por se fixar como características da própria música. De acordo com Virgínia de Almeida Bessa, o processo de gravação, por exemplo, influenciou na instrumentação escolhida pois,

[...] as sonoridades típicas do jazz [...] podiam ser registradas e reproduzidas em disco com grande "fidelidade" (ou seja, mantendo muitas das características sonoras que se escutava na performance ao vivo). O mesmo não ocorria com a música de concerto nem com os gêneros de música ligeira executados pelas orquestras tradicionais, cujos timbres não eram captados com precisão. [...] os principais instrumentos a participarem das primeiras gravações elétricas, a partir de 1927, seriam justamente o pistom, o trombone, o saxofone, o piano, o banjo, o violão e a bateria [...]. Os violinos também receberiam algum destaque, sobretudo nas gravações de músicas lentas. Mas o fagote, o oboé, a trompa, a viola, o violoncelo e outros instrumentos sinfônicos foram condenados ao esquecimento. ${ }^{69}$

Também Orestes Barbosa, em 1933, reconheceu que a técnica dos cantores variou na hora de gravar. Contou o caso de um barítono que, por cantar impostado, seguindo a técnica do canto lírico, ao voltar ao Rio de Janeiro não pôde competir com os novos cantores habituados ao

68 CAVALCANTI, Alberto R. Música popular: janela-espelho entre o Brasil e o mundo. 2007. 404 f. Tese (Doutorado em Sociologia) - Instituto de Ciências Sociais, Universidade de Brasília, 2007. p. 66.

69 BESSA, Virgínia de Almeida. A escuta singular de Pixinguinha. História e música popular no Brasil dos anos 1920 e 1930. São Paulo: Alameda, 2010. p. 177. 
microfone, "porque hoje cantando não se berra mais"70. O mesmo Mário de Andrade, em "Terapêutica musical" (1939), diferenciou a velocidade do ritmo na música folclórica e na música gravada:

[...] a música popular brasileira raríssimamente, a bem dizer nunca, atinge os andamentos rápidos que vão do "presto" ao "prestíssimo". O presto de algumas emboladas e modinhas urbanas que escutamos em discos, é criação artificial, provocada pela influência da música erudita ou semi erudita, importada da Europa e dos Estados Unidos. ${ }^{71}$

Não por acaso, Mário de Andrade afirmou que "são as grandes casas de fonografia que se incumbem atualmente da fixação e evolução da nossa dança cantada"72. Efetivamente, já desde 1927, o catálogo da Victor Talking Machine orgulhava-se de apresentar Nathaniel Shilkret, seu gerente e diretor musical, fazendo o seguinte reconhecimento:

Actualmente no hay otro hombre que haya hecho tanto por la música popular en el Nuevo Mundo como Nathaniel Shilkret. Él ha invertido el proceso muy común de tomar material de los grandes clásicos de la música y remodelarlo para el consumo popular. En vez de esto, Shilkret ha tomado la efímera música popular, y refundiola en los perennes moldes del divino arte de la música. ${ }^{73}$

Certamente, a música que circulava nos discos começava a ter uma fisionomia própria e, resulta curioso, que nos últimos anos de vida, Mário de Andrade reduziu o uso da expressão "música folclórica" e, em contraposição, usou com maior frequência o termo "música popularesca", para se referir a ela.

No fundo, o uso dos adjetivos "popularesca" e "populachera" - como foi ilustrado por Emirto de Lima no começo do artigo - indicava 1) o reconhecimento de uma música similar, mas não igual à popular folclórica; 2) a circulação em discos e na rádio dessa música; 3) a necessidade quase inconsciente de dar um nome especial ao novo tipo de música e, sobretudo,

70 BARBOSA, Orestes. Samba: sua história, seus poetas, seus músicos e seus cantores. [1933] Rio de Janeiro: Livraria Educadora; MPB reedições Funarte, 1978. p. 68.

71 ANDRADE, Mário de. Terapêutica musical [1939]. In: ALVARENGA, Oneyda (org.). Namoros com a medicina. São Paulo: Livraria Martins Editores, 1972. p. 17.

72 Idem. Carnaval tá aí [1931]. LOPEZ, Telé Ancona (org.), op. cit., p. 321.

73 Catálogo de Discos Victor: 1927 con material biográfico, anotaciones sobre óperas, fotografias de artistas y otras... New Jersey: Victor Talking Machine, 1927, p. 7 . 
4) denunciava as tensões entre o conceito romântico de popular, alimentado pelo nacionalismo musical, e o novo popular das culturas urbanas.

Embora a historiografia costume destacar no termo "popularesca" uma forte conotação pejorativa, observou-se que a palavra foi usada basicamente para dizer "[...] feito à feição do popular [...]"74. Conforme analisado anteriormente, parece que o termo empregado por Mário de Andrade para se referir a uma música desprezível foi "submúsica", aquela caracterizada por ganhar "o aplauso fácil”. Apesar de, em seus escritos, Mário de Andrade não ter utilizado "popularesco" com um sentido desfavorável, parece que alguns de seus contemporâneos, ou o próprio autor, em outros contextos, usaram "popularesco" como um adjetivo que desvalorizava certa música popular.

Por outro lado, deixa-se para futuras pesquisas a especulação a respeito da carga pejorativa atribuída ao conceito "música popularesca" como uma construção historiográfica e não uma particularidade do pensamento musical de Mário de Andrade. À luz das leituras feitas, observou-se que seu uso não se restringiu a qualificar a música popular urbana, mas também a algumas peças de procedência erudita, todas apreciadas pelo musicólogo. Possivelmente, o desdém com que alguns de seus contemporâneos contemplaram a música midiatizada seja o primeiro responsável pela distância que se encontrou entre os escritos de Mário de Andrade e o uso do termo na historiografia musical brasileira. Não obstante, o escritor modernista expressou um forte desprezo por um tipo de música que denominou como "submúsica", aquela que considerou de ínfimo valor por apelar para recursos fáceis, a fim de ganhar a aceitação rápida do público, encontrada tanto nos teatros e em seus músicos virtuosos quanto na rádio e nos discos.

\section{Sobre a autora}

\section{Juliana Pérez González}

Doutoranda em História Social na Faculdade de Filosofia, Letras e Ciências Humanas da Universidade de São Paulo (USP, São Paulo, SP, Brasil).

E-mail: julianabe@hotmail.com

74 ANDRADE, Mário de. A música e a canção populares no Brasil. Ensaio crítico-bibliográfico [1936]. In: ALVARENGA, Oneyda (org.). Ensaio sobre a música brasileira. São Paulo: Livraria Martins Editora, 1972. p. 167. 